Egyptian Journal of Aquatic Biology \& Fisheries

Zoology Department, Faculty of Science,

Ain Shams University, Cairo, Egypt.

ISSN $1110-6131$

Vol. 24(6): 383 - 392 (2020)

www.ejabf.journals.ekb.eg

\title{
Biometric and histological studies of the shellfish Paphia undulata infested with parasites
}

\author{
Osama Ward $^{1 *}$, Shereen Fahmy ${ }^{1}$, Rabab Alkaradawe ${ }^{2}$ and Samya Mohammad ${ }^{3}$
}

1. Departments of Zoology, Faculty of Science, Damietta University, Egypt.

2. Departments of Zoology, Faculty of Science, El- Arish University, Egypt.

3. Departments of Zoology, Faculty of Science, Port Said University, Egypt.

"Corresponding Author: osama_ward2008@yahoo.com

\begin{abstract}
ARTICLE INFO
Article History:

Received: July 7, 2020

Accepted: Sept. 8, 2020

Online: Sept. 17, 2020

Keywords:

Mediterranean Sea, clam,

Paphia undulata, protozoan parasites, histopathology.
\end{abstract}

\begin{abstract}
The present study reported parasites and its histopathological effects on the tissue of the popular seafood clam Paphia undulata. Some parasites were found to have several effects on shellfish aquaculture production. Samples of clams were collected from Damietta shore, Egypt. Histopathological examination was conducted on the gills, gonads, and intestine of clams. Two types of parasites were detected in the infected clams (protozoans and nematodes). The identification of Protozoa was confirmed by using the electron microscope. This study revealed that $51 \%$ of $P$. undulata were infected with parasites. The highest infection was noticed in the clam size ranged from 2.1 to $4 \mathrm{~cm}$. This infection declined with the larger clams. The current study proved that there was a negative association between the prevalence of parasites and clam size. Histopathological effects of parasites on the clam gills, gonads, and intestine were detected. Parasites not only affect clams but may also be transmitted to consumers after eating undercoocked shellfish. So, this study warns against eating raw seafood as it is considered a vehicle for the transmission of human parasites.
\end{abstract}

\section{INTRODUCTION}

Worldwide, people obtain great part of their animal protein from shellfish. Bivalves are key components of marine environments because, as filter feeders, they play a critical role in maintaining water quality and ecosystem integrity (Lee et. al., 2001). Bivalves are abundant resources for the shore inhabitants (Dumbauld et. al., 2009). The clam Paphia undulata of the family Veneridae is among the most popular eatable clam and is consumed locally in Egypt. It was noticed that clam population declined across the Egyptian fisheries in the past decade. This is mostly attributed to overexploitation, pollution and parasites (El-Gamal, 2010). Parasites infect many species of marine bivalves throughout the world (Hine and Diggles 2002). Mass mortality of bivalves was recorded to be associated with presence of parasites (Lee et. al., 2001). Studies on 
parasites and diseases of bivalves are important since they provide the essential knowledge for maintenance of natural resources. As reviewed by Boehs et.al. (2012), the main records of pathogens in the bivalves included protozoa and some metazoa. Clams feed on suspended phytoplankton by trapping it in the gills. Simultaneously, the gills also filter pathogenic microorganisms from the water, concentrating them in the digestive system (Robertson, 2007). Some parasites cause a reactive hyperplasia of the epithelium and increased mucus production on aquatic animals. Hyperplasia appears as a cloundiness to the skin and leads to hypoxia if occur on the gills (Purivirojkul, 2012). Protozoan parasites within the genera Haplosporidium and Perkinsus severely affect mollusc species around the world. Haplosporidium nelsoni was associated with mass mortalities of oysters in the USA (Messerman et. al., 2012). Protozoan parasites of the genus Perkinsus are known to infect many species of marine molluscs including oysters, abalones, clams, scallops, cockles, and mussels. Perkinsus olseni infected populations of Pitar rostratus (Cremonte et. al., 2005). Perkinsus marinus and Perkinsus olseni cause "Dermo" disease (Bushek et. al., 2002). On the other hand, species of Bonamia, haplosporidian protozoan are parasites which infect haemocytes of several bivalve species as stated by Carnegie and Cochennec-Laureau (2004). Some parasitic Amoebae can infect the external surface, such as gill and skin, and internal organs such as intestine. Paramoeba pemaquidensis caused chronic mortality (Purivirojkul, 2012). Young et. al. (2007) and Bustos et. al. (2011) considered Neoparamoeba perurans as agent of gill disease. Meanwhile, Toxoplasma gondii and Cryptosporidium parvum are widely distributed pathogens of humans and animals that may retain their infectivity in raw or undercooked mollusks (Hohweyer et. al., 2013). Lindsay et. al., (2004) stated that infected oysters Crassostrea virginica may serve as a source of $T$. gondii for marine mammals and humans, since oysters can readily acquire $T$. gondii oocysts from seawater. Oocyst stage of $C$. parvum was also detected in many oysters, mussels and clams (Robertson, 2007). Hepatopancreatic tubules of the heavily infected shrimp by microsporidian infection were dilated and necrotic (Prasertsri et. al., 2009). Few species of nematodes could be found as larval stages in bivalve tissues. However, the presence of protozoan and metazoan pathogens are capable of producing significant production loses. The aim of the current study is to: 1) investigate the parasites in P. undulata, 2) describe the possible pathogenic effect of these parasites on the clam tissue.

\section{MATERIALS AND METHODS}

Clam specimens were sampled from Izbet EL-Borg at the connection between the River Nile and the Mediterranean Sea in Damietta governorate, Egypt. Then samples were immediately transported to the laboratory for examination. Clam soft tissue was removed from the shell, transverse section was cut in the middle of the body to allow fixative to penetrate tissues and tissue was then preserved in fixative solution for $24 \mathrm{~h}$. It dehydrated with graded ethanol, cleared with xylene, embedded in paraffin wax and sliced to $5 \mu \mathrm{m}$ transverse sections. Sections were stained with Hematoxylin-eosin and examined under light microscope (XSZ-107BN). Photos were taken using microscope equipped digital camera (AMCAM camera).

Specimens were prepared for scanning electron microscope (SEM). Small pieces of infected tissue of $P$. undulata were fixed in glutaraldehyde followed by dehydration. 
Critical point drying, Drying with hexamethyl disilazane (HMDS) and tert-Butanol, coating with Gold/Palladium using Sputter coater and Image processing (Software Scandium).

\section{RESULTS}

The investigated clams were in the range $3.2-6.2 \mathrm{~cm}$. The present study showed that the ratio between the infected and non infected clams was equal (1:0.96). Infection of clams was noticed by two types of parasites (protozoan and nematode parasites). Protozoa were inferred by the presence of single-celled eukaryotes, with an external plasma membrane which encloses the cytoplasm and one or more nuclei (Fig.1). Locomotors organelles like pseudopodia were present. Pseudopodia appear as temporary extensions of the cytoplasm which elongate the plasma membrane. Our result was confirmed by scanning electron microscope (SEM) that appeared in Fig. (2)

Fig. (3) exhibited egg of nematode that may be identified as Trichuris trichiura which characterized by the barrel-shaped lemon eggs. In addition to the mucus that protruded as bipolar plugs.

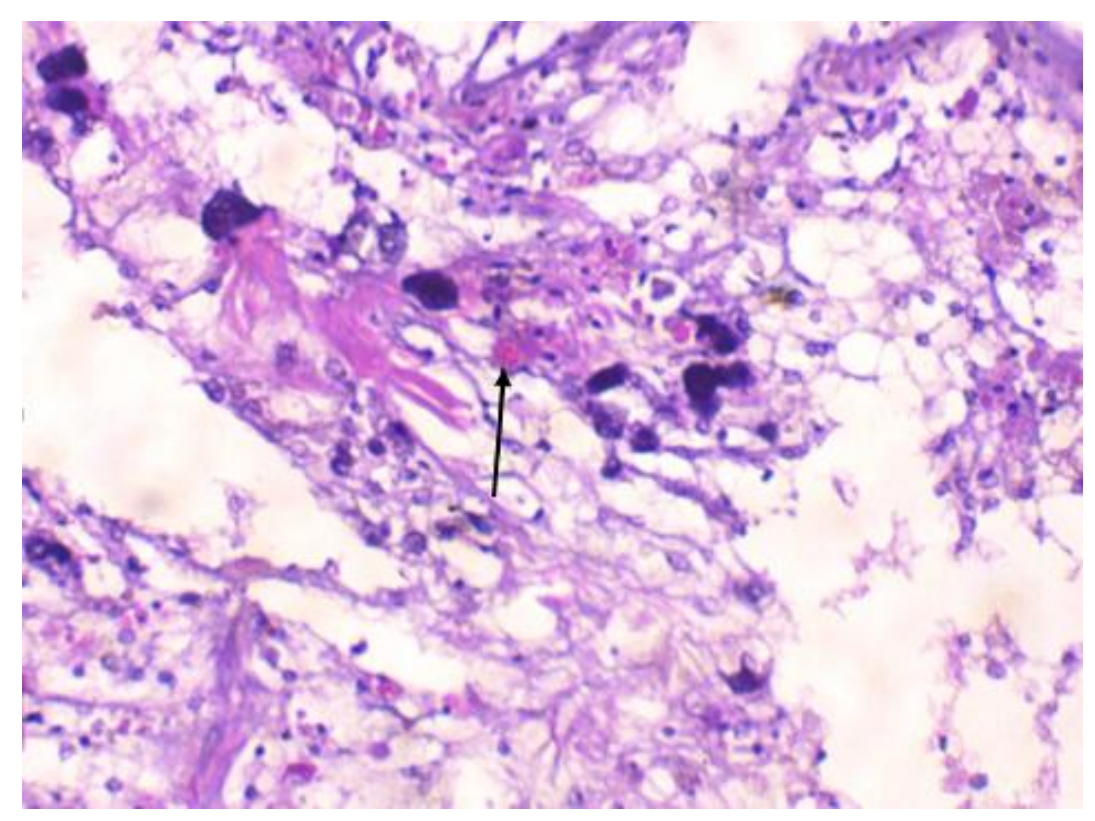

Figure 1. A photomicrograph of $P$. undulata infected by protozoan parasites. (H\&E $\mathrm{x} 100)$ 

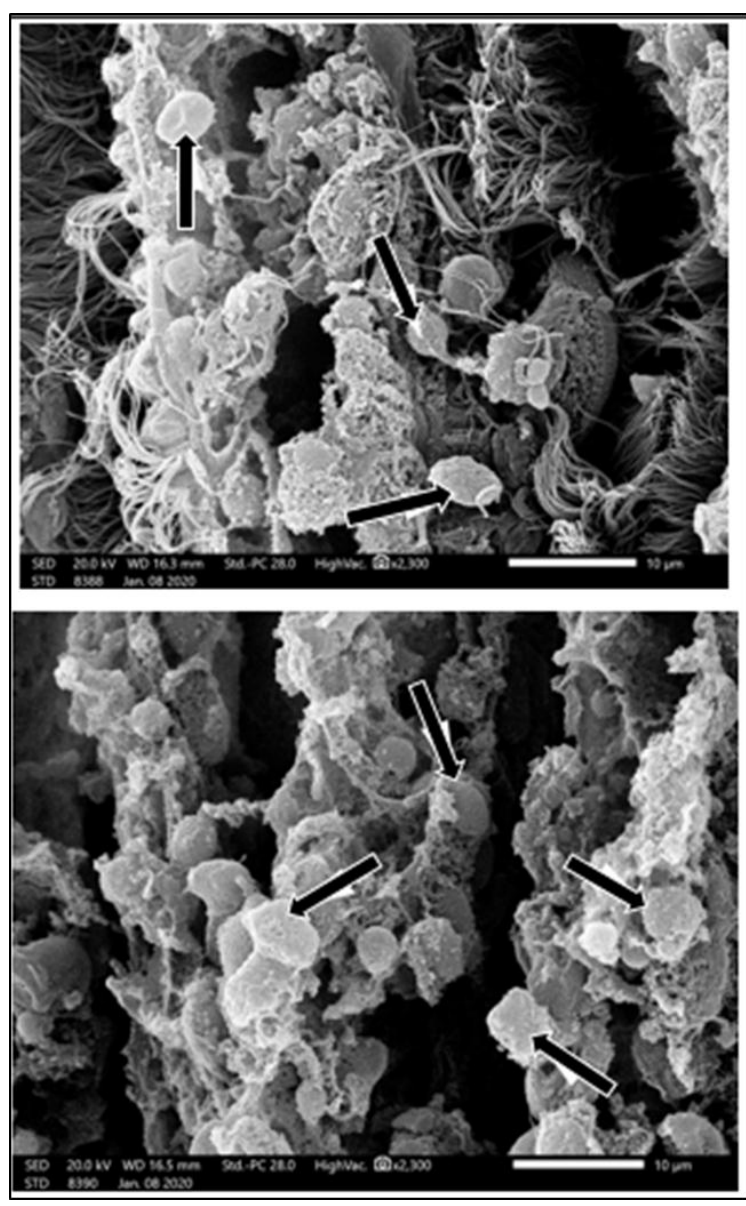

Figure 2. Scanning electron micrographs showing protozoan parasites infested $P$. undulata.

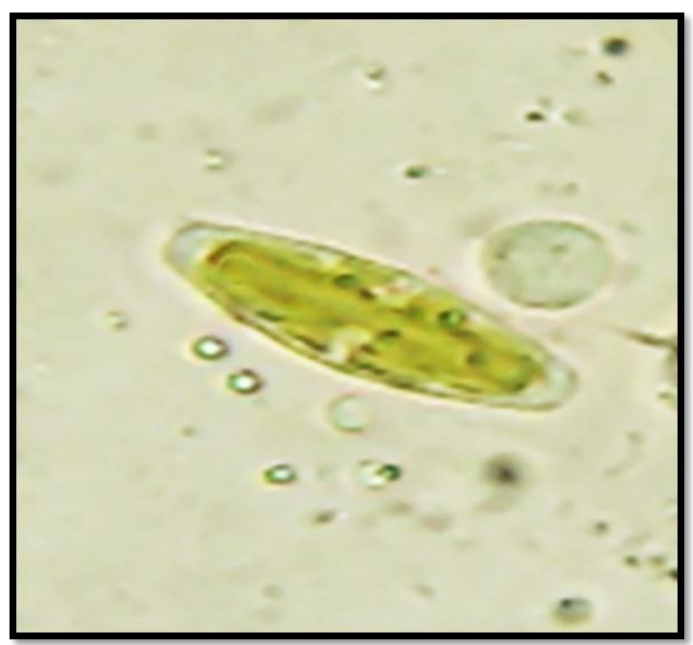

Figure 3. Smear from intestine of the infected bivalve showing nematode egg. (x100) 
Fig. (4). showing the prevalence of parasites in the infected clam P. undulata. Protozoan parasites represente $99.2 \%$, while nematode eggs was only $0.8 \%$.

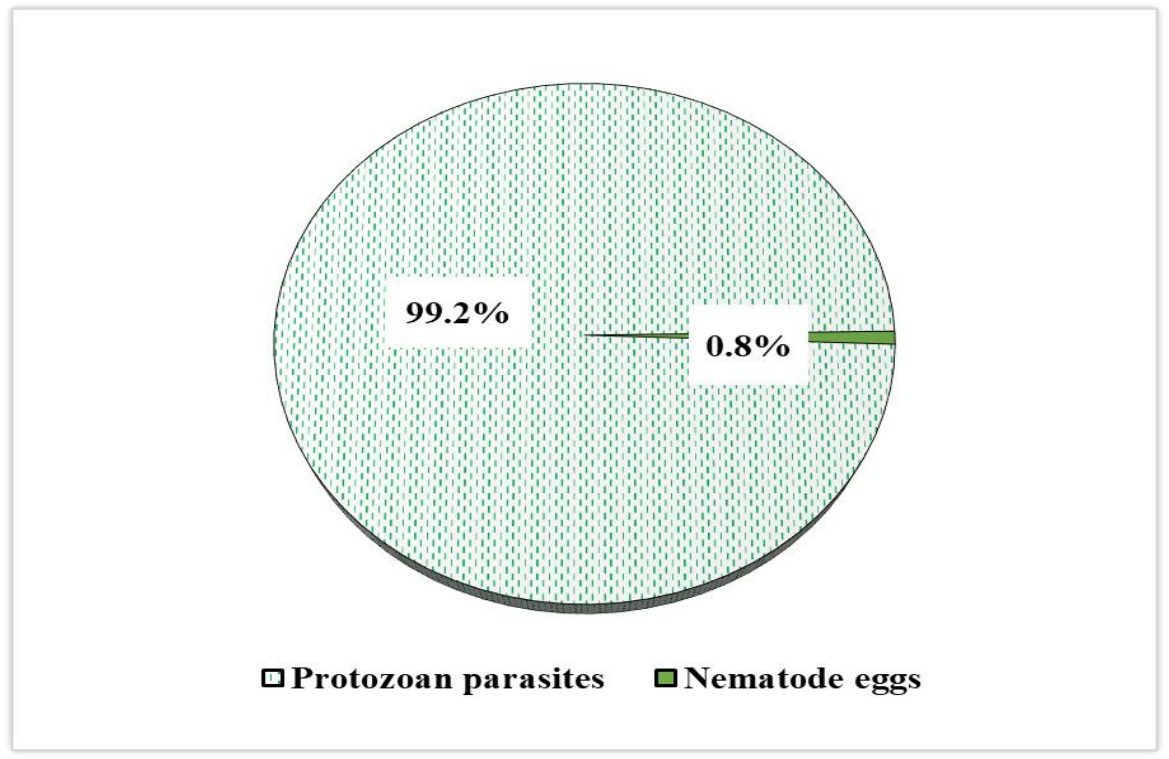

Figure 4. Prevalence of parasites in the infected clam $P$. undulata.

Abundance of parasites in relation to shell length is presented in Fig. (5). The highest infection was in the smallest length (233 individual). Then the number of parasites declined in larger sizes ( it was 144 and 10 individual in length classes 4.1-6 and 6.1-8 respectively).

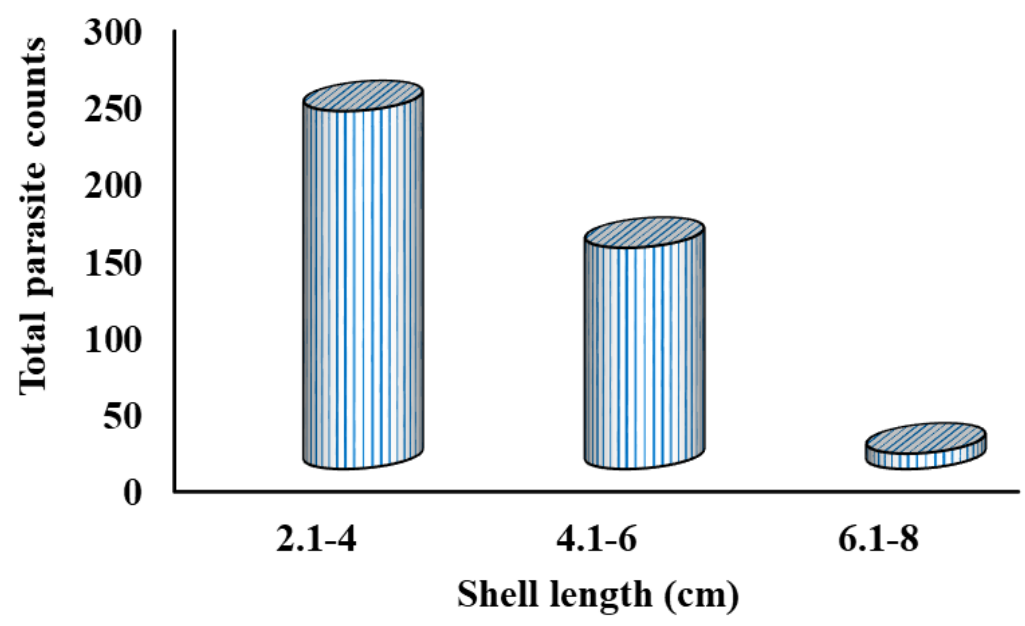

Figure 5. Abundance of parasites in relation to the bivalve shell length. 
Histopathological alterations in tissue of the infected clams was shown in Fig. (6).Gill, gonad and intestine showed changes in their tissue structure due to the infection by parasites.Gill tissue of an uninfected clam exhibited the normal organization of epithelial and connective tissues as shown in Fig. (6a). Whereas infected gill tissue showed degeneration in endothelial cells. Farthermore, bacterial colonies appeared around the parasite (Fig. 6b).

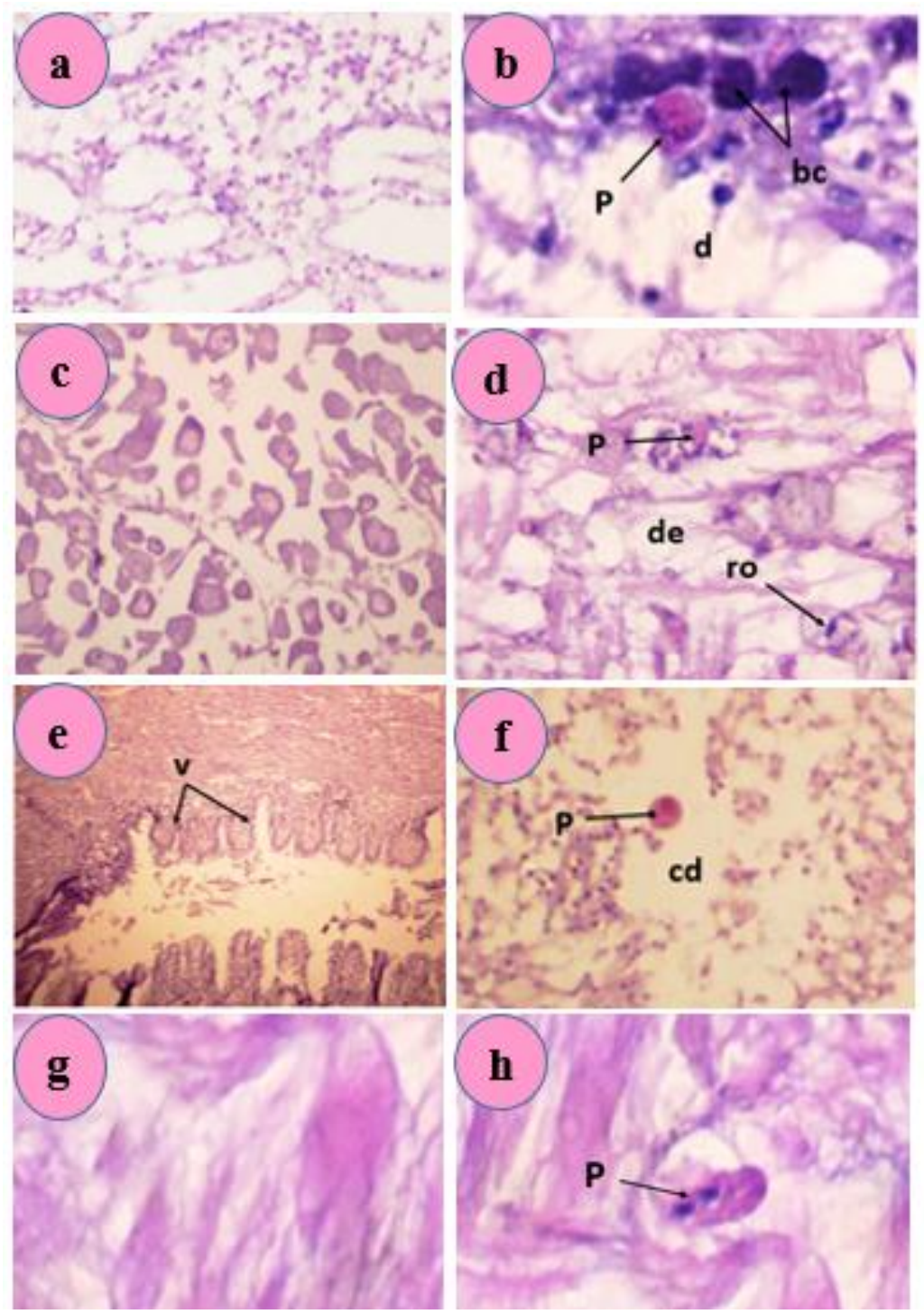

Figure 6. Photomicrographs of normal (left) and infected (right) tissues of P. undulata stained with H\&E stain (100 x). a\&b: gill, c\&d: gonad, e\&f: the intestine g\&h: connected tissue surrounding the intestine. Abbreviations: (p) protozoan parasites, (d) degenerated gill tissue, (bc) bacterial colonies around the parasite, (ro) residual ova, (v) intestinal villi, (cd) complete degeneration of intestinal cells around protozoan parasites. 
The normal structure of gonad tissue with a few ova was shown in Fig. (6c). The presence of protozoa in gonads was associated with gonad follicle destruction (Fig. 6d). Interfollicular space become very noticeable.Few residual ova in some follicles undergoing degeneration which was easily detected by the loss of its round shape. The normal structure of intestinal tissue was shown in Fig. 6e.Damage in intestinal wall and lysis of the infected cells were also appeared in the intestinal tissue (Fig. 6f).The normal structure of the connective tissue surrounding the intestine was shown in Fig. 6g. Degeneration in the connective tissue around protozoan parasites of the infected clam were appeared in Fig. $\mathbf{6 h}$.

\section{DISCUSSION}

Marine bivalves are favorite meal for most people, especially Egyptians. The Mediterranean Sea fishes and sea food especially in coastal waters of Egypt are considered as highly valued fish food. Edible bivalve species, such as Paphia undulata, in addition to other veneroid clams are most common to the consumers in Egypt (Mohammad et. al. 2014). However, it act as first intermediate hosts for many parasites (Cremonte et. al., 2015). The occurrence of parasites was mainly observed in the connective tissue surrounding the intestine, as well as the mantle and gill as stated by Francisco $\boldsymbol{e t}$. al. (2010). The present study concerned with the detection of parasites that infected one of the most economically bivalve, $P$. undulata. Our study showed that the overall prevalence of parasites was 51\%. This ratio was lower than detected by Francisco et. al. (2010) in another bivalve. They found that the prevalence of parasites was $70 \%$ in Mytilus galloprovincialis. The present work also elucidated that the prevalence of protozoan parasites was $(99.2 \%)$, while it was $0.8 \%$ only for nematode. A similar high value of protozoa parasites prevalence was reported by Vázquez and Cremonte (2017). They stated that Trichodina-like ciliates infected Aequipecten tehuelchus with the prevalence of $98 \%$. A previous study of Vázquez et. al. (2015) assured that the prevalence of ciliate parasites was $79 \%$ in gills of the clam Panopea abbreviata. The current study registered that the highest infection by parasites was in the clam with the shell size of $2.1-4 \mathrm{~cm}$. Then prevalence of parasites was negatively associated with the shell length. We can suggest that the negative relationship may be due to the low immunity of the small clam size. In contrast with our results, Vázquez (2012) stated that bigger clams were more frequently infected. The difference in the results between the two studies may be attributed to the difference in bivalve species. So, it can be concluded that the negative or positive relationship between number of parasites infected the clam and their shell length was largly depended on the genera or species. Cellular death due to necrosis result in the loss of cell membrane integrity and an uncontrolled release of products of cell death into the extracellular space (Proskuryakov et. al., 2003). Most of the bivalve species feed on suspended phytoplankton via a pair of specialized gills. Large volumes of water are pumped across the gills by ciliary action. Trapped food particles are transported toward the mouth by specialized cilia. Trichodina-like ciliates infected Amarilladesma mactroides and Aequipecten tehuelchus causing a distortion of the natural architecture of the gill filaments as stated by Vázquez and Cremonte (2017). They added that mass mortalities were associated to severe infection as the case of 
cockles and oysters. Several studies also reported that heavy infection of Perkinsus spp. in clams often results in milky-white pustule formation in clam mantle and gill tissues as a consequence of inflammation (Choi et. al., 2002). The histopathology of gills in the present work reported the degeneration in endothelial cells of gills. Additionally, the current study revealed the presence of bacterial colonies appeared around the parasite in gill tissues. These histopatholigical changes might lead to reduction or a complete loss of function as the gills lost its normal structure. Histological sections of the infected mussels with Prosorhynchus crucibulum revealed a marked reduction in the reproductive tissue. This promotes a severe damage to its reproductive capacity (Francisco et. al., 2010). This result was similar to the result in the present study which recorded destruction of gonad follicle and degeneration of the ova in some follicles. The current work exhibited lysis of the intestinal cells and degeneration of the connective tissue surrounding it. In some cases, parasites can destroy host tissue (Purivirojkul, 2012). Trophozoites of Perkinsus olseni evoking a severe haemocytic infiltration into the surrounding tissue (Vázquez and Cremonte, 2017). Most of the microscopic signs of Bonamia spp. infection are the haemocytic infiltration in all the connective tissue (Kroeck and Montes 2005).

Understanding the physiology of the bivalves helps clarify why people become infected after eating raw shellfish. The shellfish are common in areas where nutrient levels are high and waters are sheltered. Unfortunately, such conditions prevail in shallow waters, which are frequently contaminated with human sewage. When pathogenic microorganisms contaminate the harvesting sites, they are filtered by the gills and are transported to the mouth and intestine. So, we can suggest that this is the reason why we found the egg of $T$. trichiura in the intestine and gill of the clam. Its low prevalence may be interpieted as few species of nematodes could infect the bivalves. This was previously assured by Vazquez and Cremonte (2017) who mentioned that nematodes frequently appear in low prevalence and intensities of infection. The data collected in the present study showed that the study site is considered moderately infested with parasites. So, eating unproper cooked infected bivalve may cause a zoonotic disease. If these pathogens are not cleared or inactivated by the bivalves, their consumption might pose a public health concern and impact the costal economies in the event of temporary or long-term closure of the affected areas.

\section{REFERENCES}

Boehs, G.; Magalhães, A.R.M.; Sabry, R.C. and Ceuta, L.O. (2012). Parasites and pathologies of economically important marine bivalves off the Brazilian coast. In: Silva-Souza AT, Lizama MLA, Takemoto R, organizers. Pathology and Health of Aquatic Organisms. Maringa: ABRAPOA; pp.165-194.

Bushek, D.; Ford, S.F.; Marnita, M. and Chintala, M.M. (2002). Comparison of in vitro-cultured and wild-type Perkinsus marinus. III. Fecal elimination and itsrole in transmission. Diseases Of Aquatic Organisms. 51(4): 217-225. 
Bustos, P.A.; Young, N.D.; Rozas, M.A.; Bohle, H.M.; Ildefonso, R.S.; Morrison, R.N. and Nowak, B.F. (2011). Amoebic gill disease (AGD) in Atlantic salmon (Salmo salar) farmed in Chile. Aquaculture; 10(3): 281-288.

Carnegie, R.B. and Cochennec-Laureau, N. (2004). Microcell parasites of oysters: Recent insights and future trends. Aquat Living Resour; 17(4): 519-528.

Choi, K.S.; Park, K.I.; Lee, K.W. and Matsuoka, K. (2002). Infection intensity, prevalence and histopathology of Perkinsus sp. in the Manila clam, Ruditapes philippinarum, in Isahaya Bay, Japan. J Shellfish Res; 21(1): pp. 119-125.

Cremonte, F.; Balseiro, P. and Figueras, A. (2005). Occurrence of Perkinsus olseni (Protozoa: Apicomplexa) and other parasites in the venerid commercial clam Pitar rostrata from Uruguay (Southwest Atlantic coast). Dis Aquat Organ; 64(1): pp. 8590 .

Cremonte, F.; Gilardoni, C.; Pina, S.; Rodrigues, P. and Ituarte, C. (2015). Revision of the family Gymnophallidae Odhner, 1905 (Digenea) based on morphological and molecular data. Parasitology International; 64(2): pp. 202-210.

Dumbauld, B.R.; Ruesink, J.L. and Rumrill, S.S. (2009). The ecological role of bivalve shellfish aquaculture in the estuarine environment: a review with application to oyster and clam culture in West Coast (USA) estuaries. Aquaculture; 290(3-4): pp. 196-223.

El-Gamal, M.M. (2010). Detection of trematode larvae in Donax truculus (Mollusca: Bivalvia) from Egypt. In: Proc. 6th Intl. Conf. Biol. Sci. (zool), 6: pp. 296-305.

Francisco, C.; Hermida, M. and Santos, M. (2010). Parasites and Symbionts From Mytilus galloprovincialis (Lamark, 1819) (Bivalves: Mytilidae) of the Aveiro Estuary Portugal. The Journal of Parasitology, 96(1), pp. 200-205.

Hine, P.M. and Diggles, B.C. (2002). The distribution of Perkinsus olseni in New Zealand bivalve molluscs. Surveillanc;e 29(1): pp. 8-11.

Hohweyer, J.; Dumètre, A.; Aubert, D.; Azas, N. and Villena, I. (2013). Tools and Methods for Detecting and Characterizing Giardia, Cryptosporidium, and Toxoplasma Parasites in Marine Mollusks. Journal of Food Protection, 76(9), pp. 1649-1657.

Kroeck, M.A. and Montes, J. (2005). Occurrence of the haemocyte parasite Bonamia sp. in flat oysters Ostrea puelchana d'Orbigny farmed in San Antonio Bay (Argentina). Dis Aquat Organ; 63(2-3): pp. 231-235.

Lee, M.K.; Cho, B.Y.; Lee, S.J.; Kang, J.Y.; Jeong, H.D.; Huh, S.H. and Huh, M.D. (2001). Histopathological lesions of Manila clam, Tapes philippinarum, from Hadong and Namhae coastal areas of Korea. Aquaculture; 201(3-4): pp. 199-209.

Lindsay, D.S.; Collins, M.V.; Mitchell, S.M.; Wetch, C.N., Rosypal, A.C.; Flick, G.J. and Dubey, J.P. (2004). Survival Of Toxoplasma Gondii Oocysts In Eastern Oysters (Crassostrea Virginica). Journal Of Parasitology; 90(5): pp. 1054-1057.

Messerman, N.A.; Dickey, G. and Bowden, T.J. (2017). Prevalence of the protozoan parasite Haplosporidium nelsoni in the Eastern oyster, Crassostrea virginica, in the Damariscotta River Estuary, in Maine, USA, in 2014 and 2016 as measured by PCR. Bul Europ Assoc Fish Pathol; 37(6): pp. 235-243.

Mohammad, S.H.; Belal, A.A. and Hassan, S.S. (2014). Growth, age and reproduction of the commercially clams Venerupis aurea and Ruditapes decussatus in Timsah 
Lake, Suez Canal, Egypt. Indian journal of geo-marine sciences, 43(4): pp. 589600.

Prasertsri, S.; Limsuwan, C. and Chuchird, N. (2009). The Effects of Microsporidian (Thelohania) Infection on the growth and histopathological changes in pond-reared pacific white shrimp (Litopenaeus vannamei). Kasetsart Journal Natural Science; 43(4): pp. 680 - 688.

Proskuryakov, S.Y.; Konoplyannikov, A.G. and Gabai, V.L. (2003). Necrosis: a specific form of programmed cell death? Experimental Cell Research, 283(1), pp. $1-16$.

Purivirojkul, W. (2012). Histological Change of Aquatic Animals by Parasitic Infection. Histopathology - Reviews and Recent Advances.

Robertson, L.J. (2007). The potential for marine bivalve shellfish to act as transmission vehicles for outbreaks of protozoan infections in humans: a review. Int $\mathrm{J}$ Food Microbiol;120(3): 201-16.

Vázquez, N. (2012). Pathologies that affect commercially exploited populations of bivalve molluscs of the North American coast and the link with their life stories. PhD thesis, pp: 243, National University of Comahue, Argentina.

Vázquez, N.; Ituarte, C. and Cremonte, F. (2015). A histopathological study of the geoduck clam Panopea abbreviata from San José Gulf, North Patagonia, Argentina. J Marine Biologi Ass United Kingdom; 95(6): pp. 1173-1181.

Vázquez, N. and Cremonte, F. (2017). Review of Parasites and Pathologies of the Main Bivalve Species of Commercial Interest of Argentina and Uruguay, Southwestern Atlantic Coast. Arch Parasitol; 1(2): 112.

Young, N.D.; Crosbie, P.B.B.; Adams, M.B.; Nowak, B.F. and Morrison, R.N. (2007). Neoparamoeba perurans n. sp., an agent of amoebic gill disease of Atlantic salmon (Salmo salar L.). International Journal for Parasitology; 37(13): pp. 14691481 . 